\title{
ESSENCE AND DIRECTIONS OF HUMANITARIAN FOREIGN POLICY
}

\section{СУТНІСТЬ І НАПРЯМИ ГУМАНІТАРНОЇ ЗОВНІШНЬОЇ ПОЛІТИКИ}

\author{
Gadirova Narmin Farzaly gizi, \\ Doctoral Student \\ of the Baku Slavic University, \\ Lecturer of the Department of International Relations \\ of the Azerbaijan University of Languages
}

The aim of this article is to examine the problems of the humanitarian policy of the state, in particular, the growing role of humanitarian elements in the foreign policy of the state. It is noted that humanitarian foreign policy is distinguished by its specific features and tools. The humanitarian aspect of the state's foreign policy has always been understood as a set of actions aimed at protecting human rights, related donations, programs, declarations, etc. The methodological basis of the study was the principles of a systematic and comparative analysis, with the help of which the interconnections of political, cultural and humanitarian factors of foreign policy are examined. In accordance with the objectives and the purpose of the study, the article also uses the methods of historical and chronological analysis, which allowed us to consider the history of the transformation of strategies and forms of the country's foreign humanitarian policy. For the first time, in general, humanitarian foreign policy is seen as an important component in the total amount of state foreign policy. At the same time, the article discusses the characteristic features of the humanitarian foreign policy of the state. It is also noted that the state uses certain tools in carrying out humanitarian foreign policy. Explaining the nature of the humanitarian foreign policy of the state, the article notes that we are talking about activities aimed at ensuring human rights in the field of culture, science and education. Further, the article discusses the trends in humanitarian foreign policy. In the conclusion, the author comes to the conclusion that the bodies of diplomatic services always oppose the prevalence of violent methods in the countries of presence. Note that along with actions aimed at providing humanitarian assistance and support, states can take serious steps to protect their national interests. This aspect of politics is an important component of humanitarian foreign policy of states. It is necessary to pay attention to the fact that the vast majority of the processes mentioned above differed in a competitive environment. It was no coincidence that in many cases, scholars of world history described the period in question as an era of war.

Key words: state, foreign policy, diplomacy, humanitarian policy, culture, science, globalization.

Мета цієї статті - розгляд проблем гуманітарної політики держави, зокрема зростаючої ролі гуманітарних елементів у зовнішній політиці держави. Відзначається, що гуманітарна зовнішня політика відрізняється своїми певними особливостями та інструментами. Під гуманітарним аспектом зовнішньої політики держави завжди розумівся комплекс дій, спрямованих на захист прав людини, відповідних пожертвувань, програм, декларацій і т.д. Методологічну основу дослідження склали принципи системного і порівняльного аналізу, за допомогою яких розглянуто взаємозв'язок політичних і культурно-гуманітарних чинників зовнішньої політики. У відповідності з поставленими завданнями і метою дослідження у статті також використовуються методи історичного та хронологічного аналізу, які дозволили розглянути історію трансформації стратегій і форм зовнішньої гуманітарної політики країни. Уперше гуманітарна зовнішня політика розглядається як важлива складова частина в загальній сумі зовнішньої політики держави. Водночас у статті розглядаються характерні риси гуманітарної зовнішньої політики держави. Також зазначається, що держава використовує певні інструменти під час проведення гуманітарної зовнішньої політики. Пояснюючи природу гуманітарної зовнішньої політики держави, у статті зазначаємо, що мова йде про діяльність, спрямовану на забезпечення прав людини у сфері культури, науки і освіти. Розглядаються тенденції гуманітарної зовнішньої політики. Автор, посилаючись на багаторічний історичний досвід, зазначає, що міць держави оцінюється не тільки її економічним, науково-технічним і військовим потенціалом, але і її дипломатичною майстерністю. У висновку автор приходить до висновку, що органи дипломатичних служб завжди виступають проти переважання насильницьких методів у країнах присутності. Відзначимо, що поряд із діями, спрямованими на надання гуманітарної допомоги та підтримки, держави можуть робити серйозні кроки щодо захисту своїх національних інтересів. Цей аспект політики становить важливий компонент гуманітарної зовнішньої політики держав. Необхідно звертати увагу на те, що переважна більшість процесів, зазначених вище, відрізнялися конкурентним середовищем. Невипадково в багатьох випадках дослідники світової історії описували розглянутий період як епоху воєн.

Ключові слова: держава, зовнішня політика, дипломатія, гуманітарна політика, культура, наука, глобалізація.

Introduction. At the present stage a specific weight of humanitarian component in the foreign policy of states tends to grow appreciably. It ought to be noted that the humanitarian foreign policy is deemed to be an important component of the foreign policy of the state as a whole. This notwithstanding, the humanitarian foreign policy is notable for its own features and instruments. Thus, under humanitarian aspect of the foreign policy of the state is meant a complex of actions aimed at protecting human rights, appropriate tolls, programs, declarations, etc. These actions are realized not only in the form of small groups but large-scale structures as well. For example, peaceful population in the area of combat operations, etc. It is understood that the humanitarian foreign policy of the state manifests itself in cases where human life, health and fundamental rights are endangered under the effect of various factors. Among factors endangering humans are the following: 
- armed conflicts;

- acts of crime and terror;

- natural and anthropogenic disasters;

- famine;

- discrimination policy, etc.

Objective of the article. The primary objective of the research article is to study main directions of humanitarian policy of the state. At the same time, the article reviews typical features of the humanitarian foreign policy of the state and actions directed to ensuring human rights in culture, science and education.

Review of last publications. It must be conceded that the importance of humanitarian foreign policy in the system of present-day international relations and cooperation is dynamically growing. An eloquent testimony to this are efforts in exploring current issues. In particular, an emphasis is laid on humanitarian dimensions of the international law. For example, former chairman of the international tribunal for Yugoslavia A. Cassese reviewed individual and human values as crucial dimensions of the effectiveness of the international law system [2, p. 57]. He went deep into public potentialities in protecting individual rights of personality at modern society with an emphasis on activities on this track as a crucial factor of the humatitarian policy of the state. Roughly of the same view is G. Robertson. The latter believed that the backbone of the humanitarian policy was to secure the unversal fairness in terms of crimes against the mankind [3, p. 32].

As a whole, a great number of research works have been created and broader debates held to explore the essense of the humanitarian system. These works included. In this respect, a D. Fassi's research "Humanitarian argument: moral history of modern epoch" is worth of particular mentioning. The work focuses on compensation nature of humanitarian activity. In other words, a primary mission of humanitarian policy is to render various, including moral support to humans. It is excatly the humanitarian policy that makes it possible to reduce confrontation worldwide and strengthen tolerance $[4$, p. 121].

As a whole, the foreign humanitarian policy of the state is none other than an essential direction of total foreign policy. From this point of view, to go deep into the foreign humanitarian poicy of Azerbaijan, it'd be appropriate to form a true notion of directions of the foreign policy, have an idea of its principles and priorities.

Of particular interest are works by M. Barnett to retrace dimensions of the humanitarian policy. The point is about Barnett's "Empire of Humanity: A History of Humanitarianism" [5, p. 23]. The researcher detailed about the origin and development of humanitarian elements in the international relations and foreign policy. Along with factors predetermining the development of the humanitarian policy, the author loses no sight of factors that restrict the process. Account has to be taken of the fact that M. Barnett lays an emphasis on "international unity" when sounding his opinion. In other words, M. Barnett evades a development genesis in the the foreign humanitarian role of the state. In fact, he incorporated a concept of unity in the international sphere. Note that a concept of unity provides for existence of mutual obligations. At this stage, moral responsibility of all members of the unity is evaluated as a matter of principle [5, p. 36]. In this respect, members of moral unity demonstrate their preparedness to render possible aid to all indigents. As viewed by M. Barnett, serving as eloquent indicator of humanitarian activity are charitable actions in favor of people unaffiliated to the unity. Proceeding from this theoretical prerequisite, M. Barnett is engaged in exploring development of humanitarian initiatives at the international level. At the same time, he retraced the institutionalization of humanitarian activity and its securing as legal norms. The researcher reviewed the process from a period that embrasced the 19 century to 2010 . Researecher's efforts on this track marked the development of his personal periodization of humanitarian dimensions as cited below:

- imperial humanism covering mid-19 century to the Second World War;

- neohumanism covering the Second World War to the end of the "cold war";

- liberal humanism covering the end of the "cold war" - present [5, p. 21].

Presentation of mine material. After gaining its independence, the Azerbaijani state faced the necessity of resolving a number of major problems, including in the first turn, maintenance and strengthening of the state independence, peace resolution to the Karabakh conflict, implementation of reforms aimed at developing the market economy and integrating the world processes. In the shortest time the independent Republic became a member of the United Nations Oraganization (UNO), Organization for Security and Cooperation in Europe (OSCE), Organization of Islamic Conference (OIC), Assosiation of Turkic States (ATS), Community of Independent States (CIS)), International Monetary Fund (IMF), Black Sea Economic Cooperation Organization (BSECO), International Bank for Restoration and Development (IBRD), Development Bank (DB) and Islamic Development Bank (IDB); Inter-Parliamentary Union (IPU), European Unity (EU), Council of Europe (CE), European Parliament (EP), NATO, etc.

It is worth reminding that the Azerbaijani Republic is seeking to benefit from political and economic potential of these organization in resolving challenges in the course of building of the independence state. It is no mere coincidence that the mentioned organizations, including UNO, UNESCO, ICESCO, CE, NATO, etc., play an important role in Azerbaijan's integration into the world community. Governed by UN Charter, OSCE ans CE principles, other international standards adopted by world governments, the Azerbaijani Republic has been expanding largescale collaboration with authoritative international organizations. Covering wide range of political, economic, cultural, humanitarian, military areas, the col- 
laboration of this sort enables Azerbaijan to meet interests of the country and strengthen mutually beneficial relations with leading powers worldwide [1, p. 360].

It is important to note that the humanitarian foreign policy of the state includes, in the first turn, rendering various aid, support and protectrion. Note that the support as a crucial component of the humanitarian policy includes the below-cited:

- aid to refugees and forced migrants;

- aid to persons aggrieved due to natural disaster;

- aid to peace residents in fighting zone;

- food aid;

- long-term restoration and development programs;

- other kinds of aid.

Note that the support may as well be regarded as an important component of the humanitarian foreign policy. The support primarily embraces science, education, health and other projects. However, the support does not confine to the above. Thus, the support provides for implementation of employment programs to open up new possibilities for citizens. Also involved in the implementation of support programs within the framework of the humanitarian foreign policy are activities of international and regional organizations. The present stage is notable for a tendency toward preparation and implementation of support programs over specific regions and directions.

One of the crucial directions of the humanitarian foreign policy of the state is the security of peace population. In contrast to the two components mentioned above, support to the protection of lives and tranquility of civilians is rendered insufficiently which is explained as being due to the fact that potentialities of states and international organizations on this track are rather restricted. The point is that the security is characterized by a number of distinctive features. Note that, first of all, the security is ensured within the framework of rule-proclaiming and legal activity of the state. It is natural that in the course of conflict reslution and operations aimed at peace settlement of disputes, diplomatic attempts of states may be regarded as essential components of humanitarian policy in the security area. Granting this, it must be noted that protection aspects of the humanitarian foreign policy are becoming particularly topical during intra-political and international crises. It is fair to assume that actions of this sort contribute to the lessening of tensions and conflict situations and thereby to the security of lives of peace civilians.

What is important to note is that every stage is notable for its typical features. Thus, a level of the development and related principles of humanitarian policy vary depending upon various development degree of the history of mankind. At any rate, as a principal criterion testifying to the durability of the international unity comes out either humanitarian activity or policy. In other words, the probability of the formation of true unity of various peoples becomes reality due to the implementation of the humanitarian policy.
As a whole, most researchers are minded to view the specification of ethic frames of foreign policy as a manifestation of the humanitarian policy. Also, they present the formation of humanitarian elements in the international relations as humanitarization of foreign policy. It may also be interpreted differently - as "politization of ethics". This notwithstanding, approaches disclosing the essense of humanitarian elements of the foreign policy of the state are not numerous.

It should be recognized that the conceptualization of humanitarian elements in the foreign policy takes into consideration the peaceful nature of the diplomacy. In the meanwhile, the diplomacy is one of major instruments to safeguard national interests of the state. As distinct from the war, the diplomacy, throughout its history, managed to preserve the humanistic nature of its activity. At the same time, the core of the diplomacy is based on principles of rationalism. As distinguished from the war, the diplomacy comes cheaper. Researcher P. Sharp who made a great contribution to the development of the theory of the diplomacy holds that a diplomatic view at the world gives preference to a different standpoint regarding the human existence. For example, it lays an emphasis on pluralistic nature of odeas and arguments. It is the approach above that enables humans to add a sense to their own and other's life [7, p. 10]. Note that a principle of non-interference with internal life of other persons stems from diplomatic traditions. At the same time, the diplomacy is responsible for preservation of humanitarian security inside the state. In most cases the international political essense of humanistic ideas makes it possible to interfere in terms of crisis situations, even armed conflict. However, the intereference of this sort is characterized by its own distinctive features. Thus, the interference is admissible if the question is about protection of dignity and honor of a person. It is obvious that the role of the state as a moral actor is not confined to the diplomacy only. In this connection, a crucial question is meant to be answered within the framework of our reseach. What are sources and primary functions of the humanitarian activity of the state? Note that an answer to this question makes it possible to outline the humanitarian foreign policy of the state. Studies engaged in exploring primary forms of human existence provide an opportunity to consider the humanitarian activity as one of major functions of the government. Members of a community acted as a primary object of this activity. Subsequently, external frontiers of this activity essentialy broadened under the influence of various factor. In this respect, of interest are approaches of E. Servis, a wellknown American researcher. In his studies he examines primary forms of the political power. Disputing classical theories, he claims that primary statehood forms was not based on violence only. To E. Servis' thinking, one of the functions of the primary forms of the power proved to be sociality. This is to say that humanitarian foundations of the activity of the state go back to history. Most researchers believe that improvement of the 
organization of political life lies in broadening of peace methods of activity. Based on categories of authority and leadership, the power had from the outset been guided by social and humanitarian dimensions. It'd be appropriate to interpret humanitarian elements of the internal and later external policy of the state as forms of manifestation of political power. Hence, the state is one of the directions of major activity of the power. It should be stressed that from the very beginning it was permissible to view the above as compensation function of the state. Owing to this function, the society was in position to respond adequately to external challenges. Primarily, compensation mechanisms developed wihin the framework of small communities only. However, later on the borders of this community collapsed.

Thus, allowing for considerations cited above, the humanitarian functions of the state or political power go back to factors that led to its appearance.

The principal purpose of these functions was to preserve the sociality, compensate for damages and violence, comply with environmental requirements. The factors mentioned above contributed to shapening more sophisticated forms of social organization. Attempts to widen borders of human co-residence result in broadening intra-community socialization. Manifesting itself in various forms, this factor led to the essential development of mechanisms of the humanitarian diplomacy and extension of potentialities. Along with securing dignity and rights of humans, the humanitarian activity generates a mechanism to remove damages that come as a result of various factors.

It is the very nature of the humanitarian activity that makes it necessary to disclose the core of the diplomacy. The point is that the humanitarian policy is a specific form of the diplomacy. When going deep into the stratagem of the diplomacy, it becomes possible to strengthen the security. Added to this can be the fact that according to classical approaches, the diplomacy is none other than a sort of the fulfilment of purposes and tasks of foreign political line of the heads of states, governments and specialized bodies and protection of national interests on the international arena. A term "diplomacy" goes back to a Greek word "diploma." Thus, when an envoy or a messenger used to leave ancient Greece he had a letter validating his powers. The letter was titled diploma in ancient Greece [6, p. 73].
Rezults. The long historical experience goes to show that the might of the state is valued not only by its economic, scientufuc-technical and military potential but its diplomatic skill as well. Based on highly quaified diplomatic cadres, the professional diplomacy tends to testify to state's growing might. It is obvious that the diplomatic service is a principal instrument to realize foreign political priorities and contribute to the resolution of international disputes. At the same time, effectiveness of coping with current challenges on the foreign political arena is dependent upon a level of diplomatic service.

Conclusion. As a result, it should be noted that world history is rich in tense political, geopolitical relations. It is necessary to pay attention to the fact that the vast majority of the processes mentioned above differed in a competitive environment. It was no coincidence that in many cases, scholars of world history described the period in question as an era of war [5, s. 21]. Throughout history the people pursued ways out of destructive wars. It has to be kept in mind that a level of professionalism of diplomatic service is clearer apparent in the strained historical conditions. Allowing for the facts mentioned above, it is essential to use new approaches to bodies of diplomatic service. Another question is that serious changes in forms and methods of the management and organization of diplomatic structures are currently underway. Factors largely contributing to the said changes are cited below: - modernization in the system of international relations;

- globalization;

- internationalization of international relations;

- continuous increase of the influence of new information technologies on diplomatic processes;

- expansion of diplomatic activity of nontraditional actors.

It is apparent that bodies of diplomatic service are concerned about improvement of their work, both from quality and quantity points of view. Diplomatic services or, to put it bluntly, dyplomacy oppose predominance of violent methods in the foreign plicy of states. Note that along with actions directed to rendering assistance and support, the states are able to make serious steps towards maintaining their national interests. This aspect of the policy makes up an important component of the humanitarian foreign policy of the state.

REFERENCES:

1. Ә.M. Həsənov. Müasir beynəlxalq münasibətlər və Azərbaycanın xarici siyasəti. Dərslik. Bakı, "Azərbaycan" nəşriyyatı, 2005. $631 \mathrm{~s}$.

2. Cassese A. The Human Dimension of International Law. Oxford: Oxford University Press, 2008. 700 p.

3. Robertson G. Crimes against Humanity: The Struggle for Global Justice. L. : Penguin. 2002. P. 32.

4. Fassin D. Humanitarian Reason: A Moral History of the Present. Berkeley, CA : University of California Press. 2011. $352 \mathrm{p}$.

5. Barnett M. Empire of Humanity. A History of Humanitarianism. Cornell University Press. Ithaca and L. 2011. 296 p.

5. Колосов В.В., Туровский Р.Ф. Современные государственные границы: новые функции в условиях интеграции и приграничное сотрудничество. Известия РАН. Серия географическая. 1998. № 1.

6. Торкунов А.В. Дипломатическая служба. Москва : «Российская политическая энциклопедия» (РОССПЭН), 2002. $688 \mathrm{c}$.

7. Sharp P. Diplomatic Theory of International Relations. 2000. P. 10. 